Aljaž PLEVNIK

\title{
Hitre železniške povezave - naslednji slovenski infrastrukturni projekt stoletja?
}

Hitra železnica Slovenija Železniška infrastruktura

High speed railway Slovenia Railway infrastructure
Razprava o gradnji omrežja hitrih železniških povezav na ozemlju RS postaja po vstopu Slovenije $\checkmark$ EU vse aktualnejša. Na pobudo Italije se razpravlja predvsem o podaljšanju hitre železniške proge $v$ V. prometnem koridorju iz Trsta prek Slovenije proti vzhodu. To smer povezovanja prevzemajo tudi prostorski in prometni strateški dokumenti RS, čeprav so se $v$ strokovni javnosti pojavljali dvomi o smotrnosti izgradnje tovrstnega omrežja na našem ozemlju pa tudi o primernosti povezovanja $v$ smeri $V$. koridorja. V prispevku želimo s pregledom strateških in programskih dokumentov s področja razvoja železniške infrastrukture $v$ RS in EU argumentirati potrebo po čimprejšnji celostni presoji razvojnih možnosti hitrih železniških povezav na ozemlju RS in opredelitvi nacionalnega interesa na tem področju.

\section{Uvod}

Z intenzivno gradnjo omrežja hitrih železniških povezav v Evropski uniji (EU) postaja tudi v Sloveniji (RS) vse bolj aktualna razprava o vzpostavitvi tovrstnega omrežja na njenem ozemlju. Žal se razprava vodi brez celostne vizije oziroma strateškega dokumenta države na tem področju, enako je voden in upravljan tudi celoten prometni sistem. Zato se delovanje tega izjemno pomembnega sektorja vse bolj odmika od celostnega, strateškega in dolgoročnega razmišljanja ter ukrepanja. Opaziti je težnje po ločevanju in omejevanju načrtovanja in upravljanja na posamezne prometne podsisteme in na projektno raven s kratkoročno časovno perspektivo.

Neobstoj celovitih strateških razmišljanj o razvoju prometnega sistema torej otežuje razpravo o možnih scenarijih razvoja hitrih
The debate about building a network of high speed railway connections on Slovene territory after full membership in the EU is becoming ever more pending. Following the Italian initiative discussions are mainly focused on the extension of the high speed railway in the 5th transport corridor from Trieste, across Slovenia, eastwards. This route has also been adopted in national strategic physical and transport development documents, although the professional public voiced its doubts about the feasibility of such a network in our territory, as well as suitability of connections in the 5th corridor. With a review of strategic and programme documents concerning development of railway infrastructure in Slovenia and the EU the article gives argumentation for necessary immediate comprehensive assessment of development possibilities of high speed connections in Slovenia and the definition of pertaining national interests.

železniških povezav v RS, kot jo otežuje tudi različno razumevanje pojma hitrih železniških povezav. Scenarijev razvoja te prometne infrastrukture v RS je bilo v zadnjem času precej, njihov skupni imenovalec pa sta različno pojmovanje hitrih železniških povezav ter neobstoj njihove celostne oziroma strateške preveritve. Poleg tega je bila glavnina pozornosti po osamosvojitvi namenjena iskanju trase hitre železniške proge znotraj V. panevropskega prometnega koridorja $\mathrm{v}$ smeri vzhod-zahod, drugi koridorji pa so bili zapostavljeni.

V prispevku želimo predstaviti razvoj ideje o hitrih železniških povezavah v RS v obdobju po osamosvojitvi države. S tem pregledom želimo argumentirati potrebo po čimprejšnji celostni presoji njihovih razvojnih možnosti. Presoja naj bi ponudila odgovore na temeljna vprašanja, na katera si mora odgovoriti vsaka država pred sprejemanjem odločitev 
ali dogovarjanjem s sosednjimi oziroma drugimi državami o projektu takšnega obsega in pomena - ali je gradnja take prometne infrastrukture v RS razvojno realna, ali je prometno-politično utemeljena ter ali je gospodarsko, prostorsko in okoljsko sprejemljiva.

Prvi del prispevka je namenjen opredelitvi pojma hitrih železniških povezav, v katerem se opiramo na dokumente EU in Mednarodne zveze železnic (UIC). Sledi prikaz razvoja omrežja hitrih železniških povezav v EU, ki je hkrati okvir novejših razmišljanj o tem prometnem podsistemu v RS. Osrednji del prispevka je namenjen prikazu razvoja ideje o vzpostavitvi takega omrežja na našem ozemlju in temelji na analizi relevantnih strateških dokumentov države in deloma EU.

Prispevek podaja prve rezultate projekta Razvojne možnosti železniških prog za visoke hitrosti v RS [1] katerega cilj je izdelava celostne strateške presoje razvojnih možnosti hitrih železniških povezav v RS, namen pa oblikovanje strokovnih osnov za odločanje o njihovi upravičenosti, potrebnosti in sprejemljivosti na ozemlju RS.

\section{Opredelitev pojma}

Uporaba pojma hitrih železniških povezav (in izpeljav kot npr. hitri vlaki, hitre proge itd.) je v praksi zelo široka in neenotna, saj izhaja iz različnih vidikov obravnave sistema železnic (omrežja, prevoznih sredstev, ponudbe itd.). Zato $\mathrm{Z}$ istim pojmom obravnavamo spekter ponudbe železniških prevozov, od npr. vlaka ICS Slovenskih železnic (SŽ) do vlakov s tehnologijo magnetnega lebdenja maglev. Razpon je ogromen, saj na primer povprečna hitrost ICS ne dosega 100 $\mathrm{km} / \mathrm{h}$, vlaki maglev pa na preizkusnih vožnjah presegajo $600 \mathrm{~km} / \mathrm{h}$, na prvi tržni uporabi v Šanghaju pa $440 \mathrm{~km} / \mathrm{h}$.

Delovna skupina UIC je pri poskusu oblikovanja enotne definicije hitrih železniških povezav izhajala iz treh elementov železniškega sistema (infrastrukture, voznega parka in obratovanja) ter opredelila 4 tipe povezav:

- najčistejši oziroma najbolj klasičen tip hitrih železniških povezav sestavlja omrežje prog za izključno hitre vlake (za hitrosti okrog $250 \mathrm{~km} / \mathrm{h}$ ), ki hkrati ne vozijo na drugih progah (npr. japonska centralni in zahodni shinkansen);
- drugi tip je omrežje hitrih prog, ki ga prav tako uporabljajo izključno hitri vlaki, vendar slednji vozijo tudi po klasičnih progah z enako hitrostjo kot drugi vlaki (npr. v Franciji opredeljujejo hitre železniške povezave s stališča prevoznih sredstev, neodvisno od tega, ali hitri vlaki vozijo po hitrih ali klasičnih progah);

- tretji tip je omrežje hitrih prog, ki ga ne uporabljajo samo hitri vlaki, temveč tudi klasični vlaki nižjih hitrosti, vendar hitri ne vozijo po klasičnih progah (npr. španski AVE);

- v zadnjem tipu povezav vozijo po progah za visoke hitrosti različne vrste vlakov, hitri vlaki pa tudi po klasičnih progah (npr. nemški ICE in italijanski Eurostar Italia uvrščata med hitre železniške povezave vse, ki jih opravljajo hitri vlaki, vključujoč tiste $\mathrm{z}$ nagibno tehniko) (UIC).

Očitno je torej, da je pojem hitrih železniških povezav prekompleksen za enotno definicijo, zato je smiselno, da tudi v slovenščini prilagajamo uporabo pojma izhodiščem njihove obravnave - kadar pri obravnavi izhajamo iz infrastrukture, govorimo o hitrih železniških progah ali progah za visoke hitrosti, kadar izhajamo iz prevoznih sredstev, govorimo o hitrih vlakih, integralno pa o hitrih železniških povezavah.

Temeljna razlika v pojmovanju hitrih železniških povezav med državami pa je v pragovih hitrosti, ki ločijo hitre železniške povezave (proge, vlake) od klasičnih. Že omenjeni vlak ICS med Ljubljano in Mariborom pojmujemo v RS kot hitro železniško povezavo, ki pa je hitra zaradi nižje ravni ponudbe in predvsem nizkih hitrosti, ki jih dosegajo ostali potniški vlaki na slovenskem omrežju. Hitrosti slednjih se namreč ne razlikujejo bistveno od hitrosti vlakov na začetku razvoja tega prometnega sistema pred skoraj dvema stoletjema. Hkrati so hitrosti, ki jih danes dosega najzmogljivejši vlak v ponudbi SŽ, dosegali v Evropi že v času izgradnje Južne železnice čez naše ozemlje v 19. stoletju.[2] Nasprotno je hitrostni prag hitrih povezav v državah $z$ razvitim omrežjem hitrih železniških povezav $250 \mathrm{~km} / \mathrm{h}$, čeprav nekatere alpske države (Švica, Avstrija) ugotavljajo, da je prag visokih hitrosti na železnici v tako zahtevni orografiji, kot so Alpe, nižji (SBB, 2003). Vsekakor je hitrostni prag prometnopolitično vprašanje posamezne države in izhaja iz njene prometne politike ali stra- 
tegije razvoja železnic, v katerih je opredeljena konkurenčna vloga železnic do drugih prevoznih sredstev. Zato je možno za izhodišče bodočega opredeljevanja hitrih železniških povezav v RS vzeti konkurenčnost njihovih hitrosti $v$ primerjavi $z$ daljinskim cestnim prevozom po avtocestnem križu, ki je verjetno glavni konkurent. Konkuriranje letalskim prevozom, ki ga izpostavlja EU, pri velikosti ozemlja RS ni aktualno, razen pri navezovanju našega železniškega omrežja na omrežje hitrih železniških povezav EU. Podrobnejši hitrostni pragovi take opredelitve morajo temeljiti na natančnejši analizi, ocenjujemo pa, da bi morali časi morebitnih bodočih hitrih železniških povezav med regionalnimi središči v RS in sosednjih državah najmanj prepoloviti zdajšnje čase najhitrejših železniških povezav, da bi lahko konkurirali časom povezav po avtocestah.[3]

Zaenkrat se pojem hitrih železniških povezav praviloma nanaša na prevoz potnikov. Izjema so poštni ter klasični tovorni vlaki, ki lahko ponekod v EU vozijo po hitrih progah, a so strogo omejeni in prevažajo le ponoči. V bližnji prihodnosti lahko pričakujemo tudi razvoj tovornih prevozov visokih hitrosti in s tem razširitev pojma hitrih železniških povezav na prevoz blaga.

\section{Razvoj omrežja hitrih železniških povezav $\mathbf{v}$ EU [4]}

Pojav hitrih železniških povezav v drugi polovici 20. stoletja je omogočil dvig ponudbe železniških prevozov na novo kakovostno raven in s tem njihovo konkurenčno vrnitev na trg sodobnih prevoznih storitev. Hitre železniške povezave so pomembno vplivale na prerazporeditev potniških tokov, zato se danes ta prevozni način obravnava kot učinkovita alternativa oziroma konkurenca cestne$\mathrm{mu}$ in letalskemu prometu.

Prvi razmah so hitre železnice sicer doživele na Japonskem, vendar so v zadnjih desetletjih najintenzivnejši razvoj doživele evropske $\mathrm{dr}$ žave, v katerih se z vlaki že nekaj let prevaža več kot polovica svetovnih uporabnikov hitrih železniških povezav. V zadnjem desetletju EU vzpostavlja omrežje hitrih železniških povezav s povezovanjem in širjenjem omrežij držav članic, ki že desetletja vlagajo v razvoj nacio- nalnih omrežij. EU je naddržavni formalni okvir omrežju oblikovala leta 1996 s smernicami razvoja transevropskega železniškega omrežja za visoke hitrosti. Prva hitra železniška povezava v Evropi je bila vzpostavljena leta 1981, ko so Francozi zgradili povezavo Pariz-Lyon za hitrosti do $260 \mathrm{~km} / \mathrm{h}$. Omrežje je dobilo evropsko razsežnost leta 1994 z odprtjem dela bodočega omrežja PBKAL med mesti Pariz, Bruselj, Köln, Amsterdam in London. Leta 2002 so evropske proge za visoke hitrosti skupaj obsegale $3.260 \mathrm{~km}$, od tega skoraj polovico v Franciji. Rast železniškega omrežja za visoke hitrosti nedvomno veliko prispeva $\mathrm{k}$ evropski integraciji, še več pa se pričakuje v prihodnje, saj je do leta 2020 predvidenih $10.000 \mathrm{~km}$ tovrstnih prog.

Hitri rasti evropskega omrežja hitrih železniških prog sledi tudi rast uporabnikov tega prevoznega načina. $\mathrm{V}$ desetih letih se je število potnikov na omrežju hitrih prog EU potrojilo, njihov tržni delež pa vztrajno narašča. V nekaterih državah so se po vzpostavitvi hitrih železniških povezav razmerja pri uporabi konkurenčnih prevoznih sredstev popolnoma spremenila. Pri potovanjih v EU, ki trajajo do 2,5 ure, je delež železnic pri povezavah, na katerih si konkurirata hitra železnica in letalski promet, $75 \%$, pri potovanjih do 4 ur pa $50 \%$. Do leta 2020 je v svetu predvidena 60 -odstotna rast njihove uporabe (UIC, 2002).

\section{Razvoj ideje o hitrih železniških povezavah v RS}

Ideja o hitri železniški povezavi na ozemlju RS je bila izražena že pred osamosvojitvijo države, v 80. letih, ko so tedanje Jugoslovanske železnice preučevale možen potek in tehnične elemente nove hitre proge med Ljubljano in Zagrebom v t. i. Savskem koridorju. Hitre železniške povezave so postale aktualnejše $z$ osamosvojitvijo RS, obdobje do danes pa sovpada s poudarjenim interesom Republike Italije za podaljšanje hitre železniške proge Lyon-Torino prek Trsta in RS proti vzhodu.

SŽ so leta 1992 pripravile Izhodišča SŽ za izbor trase hitre proge $\mathrm{v}$ Koridorju Ljubljana-Benetke. Odločitev o izboru koridorja oziroma smeri povezovanja so sprejele SŽ v svojih internih gradivih (Zarija: 1999, 16). 
Izbor koridorja oziroma smeri povezovanja s hitro železnico tako ni temeljil na strateškem dokumentu RS ali EU, temveč na gradivu zveze železniških prevoznikov UIC o predvidenem razvoju mreže hitrih prog v EU, ki je bil v tem obdobju bolj seštevek izraženih interesov nacionalnih prevoznikov (v primeru naše proge najbrž italijanskega) kot vizija omrežja EU. Problem je, da na tej odločitvi SŽ, ki očitno ni izhajala iz izraženih slovenskih nacionalnih interesov, temelji večina dejavnosti in razmišljanj na temo o hitrih železniških povezavah v RS v obdobju po osamosvojitvi.

Hitra železniška proga čez RS v omenjenem koridorju je prvič v katerem od uradnih dokumentov RS obravnavana 1. 1995, in sicer v Spremembah in dopolnitvah Dolgoročnega plana RS za obdobje od leta 1986 do leta 2000, ki so predvidele »preučitev smotrnosti in poteka trase nove proge za visoke hitrosti $(250 \mathrm{~km} / \mathrm{h}) \mathrm{v}$ smeri slovensko-italijanska meja-Ljubljana-slovensko-hrvaška meja« (Ur. 1. RS 72/95). Enako rešitev je predvidel tudi sočasno pripravljan Nacionalni program razvoja Slovenske železniške infrastrukture, ki je napovedal, da bo hitra proga Trst-Ljubljana-Zagreb s priključki na Koper in Reko izvedena do leta 2015 (Ur. 1. RS 13/96). Slednji dokument pri argumentaciji poteka hitre proge izhaja iz Perspektivnega načrta razvoja evropske železniške infrastrukture, ki ga je izdelala Mednarodna železniška zveza (UIC), ter iz dokumentov Združenih narodov [5], ki naj bi vsebovali zasnovo evropske mreže hitrih in glavnih prog, na katerih je temeljil v programu izbrani koridor.

Preučitev smotrnosti izgradnje hitre proge čez ozemlje RS, ki jo je predvidel prostorski plan, do danes ni bila opravljena, kljub vrsti študij na temo prometne infrastrukture za potrebe nove Strategije prostorskega razvoja RS (SPR) (Ur. 1. RS 76/2004), zato vprašanje upravičenosti in smotrnosti hitrih prog $\mathrm{v}$ RS ostaja odprto. Pristojna ministrstva so še naprej usmerjena zgolj v preučevanje obravnavanega koridorja, kar kažejo naročene študije, kot sta Prostorska preveritev tras hitre proge Trst-Ljubljana (ZARIJA: 1999) ter Strateška presoja vplivov železniške proge za visoke hitrosti na prostor ter prostorske podlage za pripravo regionalne zasnove prostorskega razvoja za Goriško (IJS, 2002). Projekta sta se ukvarjala predvsem s prostorsko umestitvijo oziroma presojo najprimernejših tras znotraj širše opredeljenega koridorja za hitro progo, ne ukvarjata pa se neposredno $s$ ključnim vprašanjem: ali so hitre železniške proge $\mathrm{v}$ RS smotrne, upravičene in realne, in če so, v kakšnem obsegu, s kakšnimi elementi, kje in kdaj.

V strokovnih podlagah za pripravo SPR oziroma $\mathrm{v}$ študiji Zasnova prometne infrastrukture v prostorskem planu Republike Slovenije (Gulič, Plevnik, 1999) je bil opravljen osamljen, čeprav omejen poskus širše obravnave možnih potekov hitre železniške proge na ozemlju RS. V njej se nismo osredotočili zgolj na koridor Trst-Ljubljana-Zagreb, temveč smo preučili tudi druge možne poteke, praviloma $\mathrm{v}$ koridorjih slovenskega prometnega križa. Strateška prostorska preveritev je pokazala, da je izbrani oziroma vrsto let obravnavani koridor iz stališča prostorskih povezav RS s sosednjimi državami in železniškim omrežjem EU manj ustrezen in da so ustreznejše druge smeri povezovanj, predvsem tiste $\mathrm{v}$ X. evropskem prometnem koridorju.

Kot smo omenili, je bila tudi preučitev omejena, in sicer na prostorsko-razvojne kazalce, in se ni ukvarjala s prometnopolitičnimi vprašanji, kot sta smotrnost ali upravičenost gradnje tovrstnega omrežja na ozemlju RS.

Čeprav preučitev smotrnosti in poteka trase nove hitre proge, ki jo je nalagal prejpnji prostorski plan, ni bila opravljena, nova SPR RS tako progo predvideva, a ne presega razmišljanj o tej problematiki $\mathrm{v}$ zadnjem desetletju. Tudi zaradi neobstoja strateških izho-

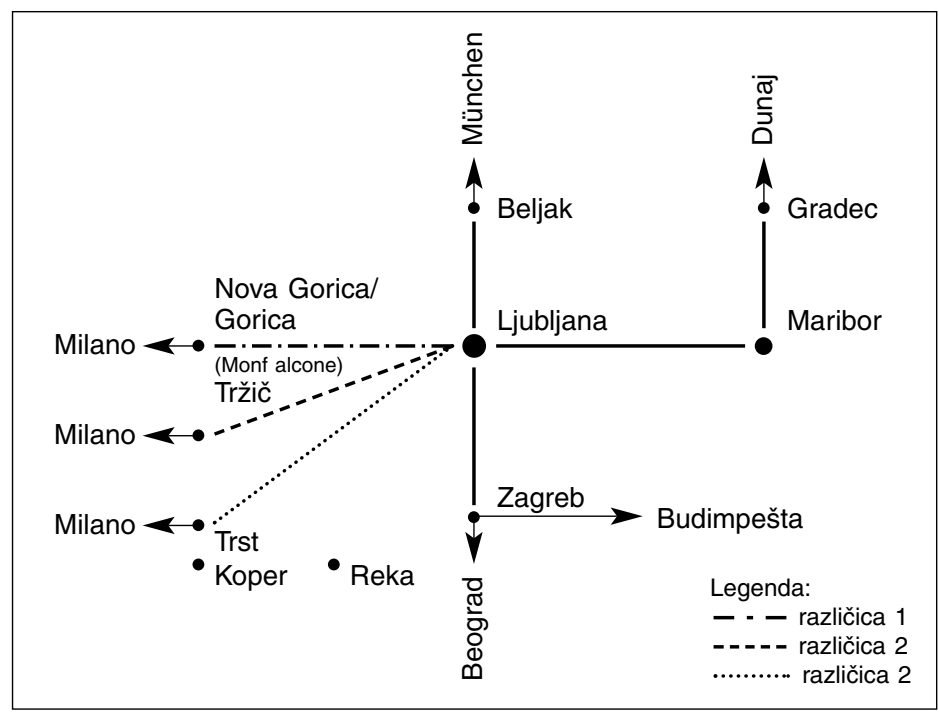

Slika 1: Možni koncept razvoja omrežja hitrih železniških povezav (Gulič, Plevnik 1999) 
dišč hitra železniška proga v SPR deluje kot tujek brez prave vpetosti $\mathrm{v}$ prometni in poselitveni sistem države. V uvodnem poglavju 2. Vsebinski pomen uporabljenih pojmov je med železniške povezave mednarodnega pomena uvrščena »hitra železniška povezava za visoke hitrosti do $250 \mathrm{~km} / \mathrm{h}$, predvidena $\mathrm{v}$ okviru V. koridorja in namenjena povezovanju središč mednarodnega pomena $\mathrm{z}$ evropskim prostorom«. V uvodnih poglavjih I. Izhodišča in cilji prostorskega razvoja Slovenije in II. Zasnova prostorskega razvoja Slovenije s prioritetami in usmeritvami za dosego ciljev prostorskega razvoja Slovenije hitra proga sploh ni omenjena, čeprav gre za osrednji del dokumenta, ki bi tako pomem-

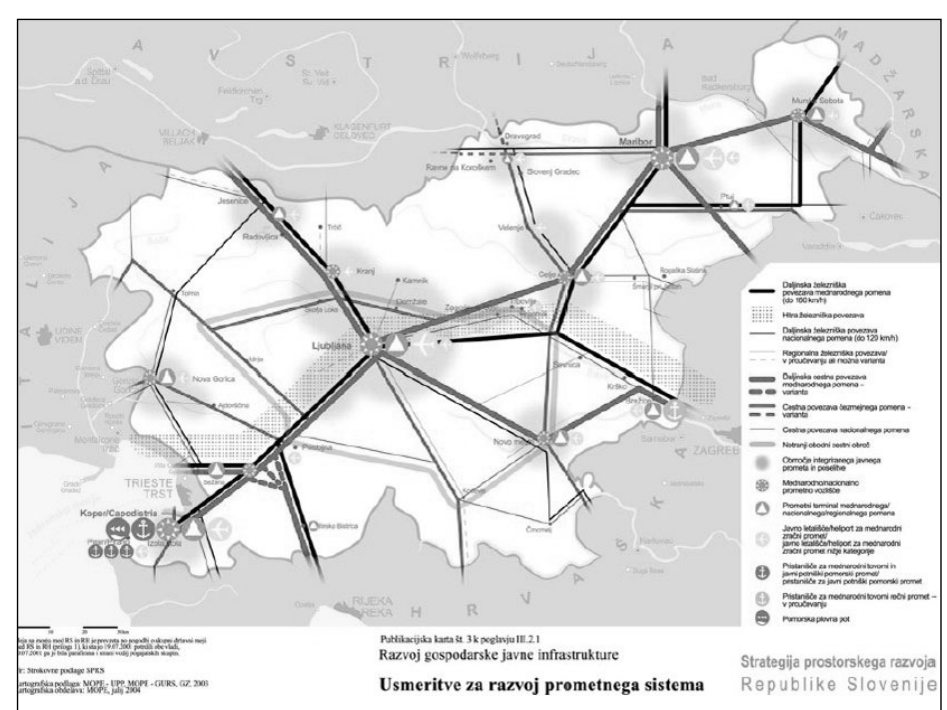

Slika 2: Prikaz koridorja hitre železniške povezave na karti Usmeritve za razvoj prometnega sistema Strategije prostorskega razvoja RS (Ur. I. RS 76/2004).

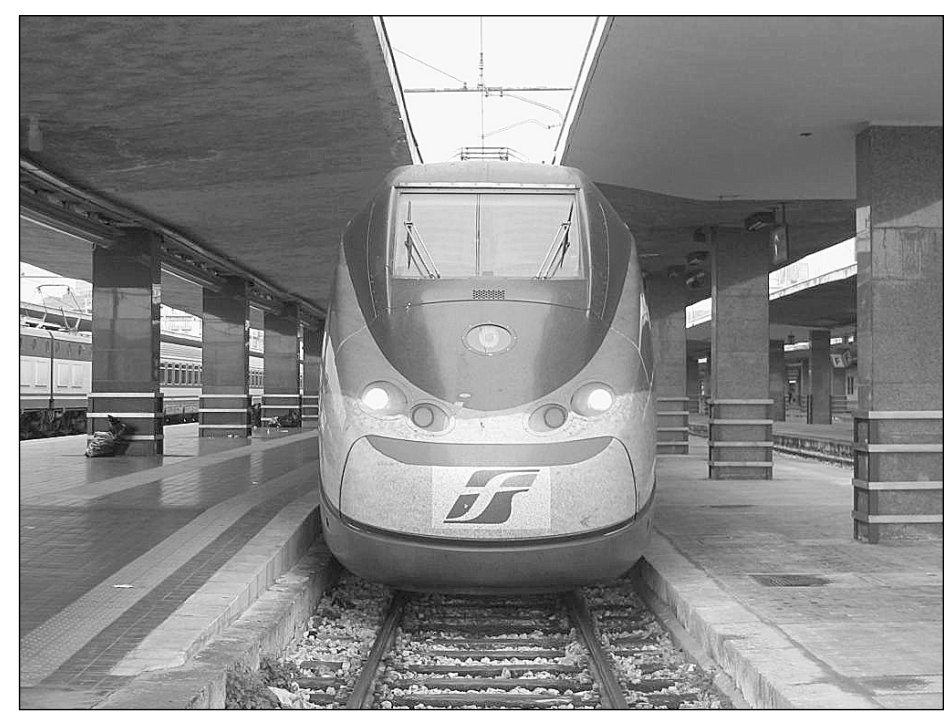

Slika 3: Italijanski hitri vlak na neapeljski železniški postaji; morda kdaj tudi na ljubljanski? (Fotografija: Aljaž Plevnik) bno infrastrukturo moral utemeljiti in nakazati njeno vlogo v prometnem in poselitvenem sistemu. Šele v poglavju III. Razvoj prostorskih sistemov z usmeritvami za razvoj na regionalni in lokalni ravni se pod 2.1.2 Železniško omrežje proga ponovno omenja, in sicer $z$ dokaj natančno opredeljenim koridorjem (Sežana-Postojna-Ljubljana-Zidani Most-Zagreb), kar je razvidno tudi iz kartografske priloge:

»...(2) Transevropska daljinska hitra železniška povezava $v$ okviru V. panevropskega prometnega koridorja, ki povezuje Benetke preko Ljubljane in Zagreba z Budimpešto, se proti severu povezuje z zmogljivimi daljinskimi železniškimi povezavami $v$ smereh od Ljubljane proti Münchnu in od Zidanega Mosta do Maribora in naprej proti Dunaju. Na daljinsko bitro železniško povezavo se naveže prometna vozlišča: na območju Divače s povezavo proti Kopru in Novi Gorici, na območju Pivke s povezavo proti Istri, na območju Ljubljane s povezavo proti Avstriji, na območju Zidanega Mostu s povezavo proti Mariboru in druge prometne podsisteme z ustrezno posodobitvijo obstoječih železniških prog $v$ koridorjih obstoječib železnic, kadar to omogočajo tehnične in tehnološke rešitve in je prostorsko racionalno.«(Ur. l. RS 76/2004).

Nič novega na tem področju ni prinesla niti Resolucija o prometni politiki RS (Vlada RS, 2004). V poglavju 5.3 Strategija razvoja prometne infrastrukture v Republiki Sloveniji je v letu 2005 predvidena Resolucija o nacionalnem programu razvoja železniške infrastrukture, ki naj bi podrobneje opredelila strategijo vzdrževanja, posodobitve in izgradnje železniške infrastrukture $\mathrm{v}$ RS v skladu Z vizijo Resolucije do leta 2020. Pomembnejša je določba za leto 2004, ko naj bi bil dosežen dogovor z Republiko Italijo o izhodiščih za pripravo študijske in projektne dokumentacije poteka bodoče hitre proge; pri tem naj bi izkoristili vse možnosti sofinanciranja iz sredstev EU. Kartografski prikaz razvoja prometne infrastrukture je predvidel uskladitev s čistopisom Strategije prostorskega razvoja RS.

Dodaten argument za strateško preučitev razvojnih možnosti hitrih prog v RS je razvoj političnih odločitev na ravni EU v zadnjem letu. Železniška proga na V. koridorju med Lyonom in Budimpešto, ki jo mnogi na- 
pačno imenujejo hitra proga, je v novejših poročilih EU o transevropski prometni mreži sicer prioriteta EU, vendar obseg in struktura vlaganj v to progo na ozemlju RS ne predvideva gradnje nove proge za hitrosti 250 $\mathrm{km} / \mathrm{h}$, temveč le modernizacijo in dograditev obstoječe za hitrosti do $160 \mathrm{~km} / \mathrm{h}$ (EC, 2003). Med izvedbenimi projekti za ta koridor je $\mathrm{v}$ tehničnem dodatku $\mathrm{k}$ poročilu skupine visokih predstavnikov opredeljena tudi študija ustreznosti, ekonomičnosti in časovne umestitve možne nove hitre železniške proge med Trstom in Ljubljano.

\section{Sklep}

Pregled strateških in programskih dokumentov s področja prometnega in prostorskega razvoja kaže, da v RS ni opredeljen nacionalni interes na področju razvoja hitrih železniških povezav, zato se med drugim pojavljajo težave pri reakcijah na vse pogostejše pobude in strategije sosednjih držav in EU. V strateških dokumentih razvoja prostora in prometa v RS se v obdobju po osamosvojitvi obravnava le hitra železniška proga $\mathrm{v} \mathrm{V}$. prometnem koridorju, ki pa je s stališča interesov RS vprašljiva. Bolj ustreza interesom sosednje Italije, ki tudi izvaja pritiske na RS s ciljem čimprejšnjega sprejema odločitve o njeni gradnji čez naše ozemlje. Hkrati je očitno, da EU v naslednjih dveh desetletjih ne načrtuje sofinanciranja gradnje novih hitrih prog na ozemlju RS, temveč zgolj modernizacijo glavnih prog za višje hitrosti. Zato je potrebno čimprej opredeliti nacionalni interes RS na področju razvoja železnic in presoditi smotrnost razvoja hitrih železniških povezav na našem ozemlju.

Dr. Aljaž Plevnik, univ. dipl. geogr. in zgod.,

Urbanistični inštitut RS, Ljubljana

E-pošta: aljaz.plevnik@urbinstitut.si

\section{Opombe}

[1] Raziskovalni projekt v okviru ciljnega raziskovalnega programa Konkurenčnost Slovenije 2001-2006, trajanje projekta 2004-2006, naročniki: Agencija za raziskovalno dejavnost, Ministrstvo za okolje in prostor, Ministrstvo za promet, izvajalci: Urbanistični inštitut RS, Ljubljana, Fakulteta za gradbeništvo Univerza v Mariboru, Prometni inštitut, Ljubljana.

[2] Leta 1848 je lokomotiva Crampton dosegla hitrost $126 \mathrm{~km} / \mathrm{h}$.

[3] Povprečne hitrosti mednarodnih vlakov v Sloveniji, ki praviloma najhitreje povezujejo pomembnejša regionalna središča $v$ državi in zamejstvu, se gibljejo okoli 70 km/h (Gulič, Plevnik 2000).

[4] Pregled razvoja v EU je povzet po UIC (2002).

[5] CER (1991): Evropska mreža prog za visoke hitrosti, Združenje evropskih železniških podjetij, Bruselj in UN-ECE (1985): Evropski sporazum o najpomembnejših mednarodnih železniških progah - AGC, Ekonomska komisija Združenih narodov, Ženeva.

\section{Viri in literatura}

EC (2003) Trans-European Transport Network up to 2020, High-Level group report. European Commission - DG Energy and Transport, Bruselj.

Gulič, A., Plevnik, A. (1999) Zasnova prometne infrastrukture v prostorskem planu Republike Slovenije: zaključno poročilo projekta $=$ Transport infrastructure development concept for the spatial plan of the Republic of Slovenia: final report, Urbanistični inštitut Republike Slovenije. Ljubljana.

Gulič, A., Plevnik, A. (2000) Analiza razvojnih možnosti prometne infrastrukture $v$ prostoru, Zaključno poročilo projekta. Ljubljana: Urbanistični inštitut Republike Slovenije

IJS (2002): Strateška presoja vplivov železniške proge za visoke hitrosti na prostor ter prostorske podlage za pripravo regionalne zasnove prostorskega razvoja za Goriško. Vmesno poročilo. Raziskovalni projekt v okviru CRP „Konkurenčnost Slovenije 2001-2006«. Nosilec projekta IJS, Ljubljana.

SBB (2003) Bahn 2000 - gut unterwegs, SBB, Zürich. UIC, CER, UNIFE (2002) High Speed Trains in Europe. Paris.

UIC: medmrežje http://www2.uic.asso.fr/d_gv/toutsavoir/definitions_en.html

ZARIJA (1999) Prostorska preveritev hitre proge Trst-Ljubljana, naročnik: SŽ - projektivno podjetje, Ljubljana, Izvajalec: Zarija d.o.o., Nova Gorica. 